\title{
PERFORMANCE EVALUATION OF SOLAR PHOTOVOLTAIC/THERMAL SYSTEMS
}

\author{
B. J. HUANG ${ }^{\dagger}$, T. H. LIN, W. C. HUNG and F. S. SUN \\ Department of Mechanical Engineering, National Taiwan University, Taipei 106, Taiwan
}

Received 6 September 1999; revised version accepted 19 September 2000

Communicated by DOUG HITTLE

\begin{abstract}
The major purpose of the present study is to understand the performance of an integrated photovoltaic and thermal solar system (IPVTS) as compared to a conventional solar water heater and to demonstrate the idea of an IPVTS design. A commercial polycrystalline PV module is used for making a PV/T collector. The PV/T collector is used to build an IPVTS. The test results show that the solar PV/T collector made from a corrugated polycarbonate panel can obtain a good thermal efficiency. The present study introduces the concept of primary-energy saving efficiency for the evaluation of a PV/T system. The primary-energy saving efficiency of the present IPVTS exceeds 0.60 . This is higher than for a pure solar hot water heater or a pure PV system. The characteristic daily efficiency $\eta_{\mathrm{s}}^{*}$ reaches 0.38 which is about $76 \%$ of the value for a conventional solar hot water heater using glazed collectors $\left(\eta_{\mathrm{s}}^{*}=0.50\right)$. The performance of a $\mathrm{PV} / \mathrm{T}$ collector can be improved if the heat-collecting plate, the PV cells and the glass cover are directly packed together to form a glazed collector. The manufacturing cost of the PV/T collector and the system cost of the IPVTS can also be reduced. The present study shows that the idea of IPVTS is economically feasible too. (c) 2001 Elsevier Science Ltd. All rights reserved.
\end{abstract}

\section{INTRODUCTION}

The present commercial solar cell converts solar energy into electricity with a relatively low efficiency, less than $20 \%$. More than $80 \%$ of the absorbed energy is dumped to the surroundings again after electric energy conversion. To raise the energy efficiency, many researchers attempted to develop hybrid PV and thermal (PV/T) collectors (Bergene and Bjerke, 1993; Bergene and Lovik, 1995; Fujisawa and Tani, 1997; Garg et al., 1990; Hayakashi et al., 1990; Lalovic, 1986/ 87).

The PV/T collector generates electric power and simultaneously produces hot water. The overall efficiency thus increases. Bergene and Lovik (1995) have shown theoretically that a total efficiency of $60-80 \%$ can be achieved with a $\mathrm{PV} / \mathrm{T}$ collector. The recent test result (Fujisawa and Tani, 1997) shows that a thermal efficiency of about $60 \%$ can be obtained for a PV/T collector. However, all the aforementioned results for thermal efficiency were the instantaneous efficiency that is calculated or measured under the conditions of once-through flow at low and constant

'Author to whom correspondence should be addressed. Tel.: +886-2-2363-4790; fax: +886-2-2364-0549; e-mail: bjhuang@tpts6.seed.net.tw inlet temperature. If the $\mathrm{PV} / \mathrm{T}$ were combined with a water tank to make a PV/T system with water heating in a closed system, the inlet temperature will vary during a day and the thermal efficiency should be rated based on a daily test result. The daily thermal efficiency of a PV/T system is not yet very clear. One of the purposes of the present study is to show how much difference in thermal efficiency there is between a $\mathrm{PV} / \mathrm{T}$ system and a conventional solar water heater.

Besides, we have noted that many conventional solar water heaters with natural circulation need parts assembled in situ. The concept of integrated design for water heating in a PV/T, i.e. integrated $\mathrm{PV} / \mathrm{T}$ system (IPVTS), is thus proposed in the present study (Fig. 1). IPVTS can be entirely manufactured in a factory with good quality control and cost reduction due to mass production. An IPVTS will be installed directly at the application site with minimal mounting work and free of assembly. The only on-site work is the connection of the hot and cold water supply lines. Hence, IPVTS has the advantage of reducing the installation cost. IPVTS also can reduce the space needed for installation and the casing cost since the PV and the thermal units are integrated within a single casing.

For demonstration purposes, we designed an 


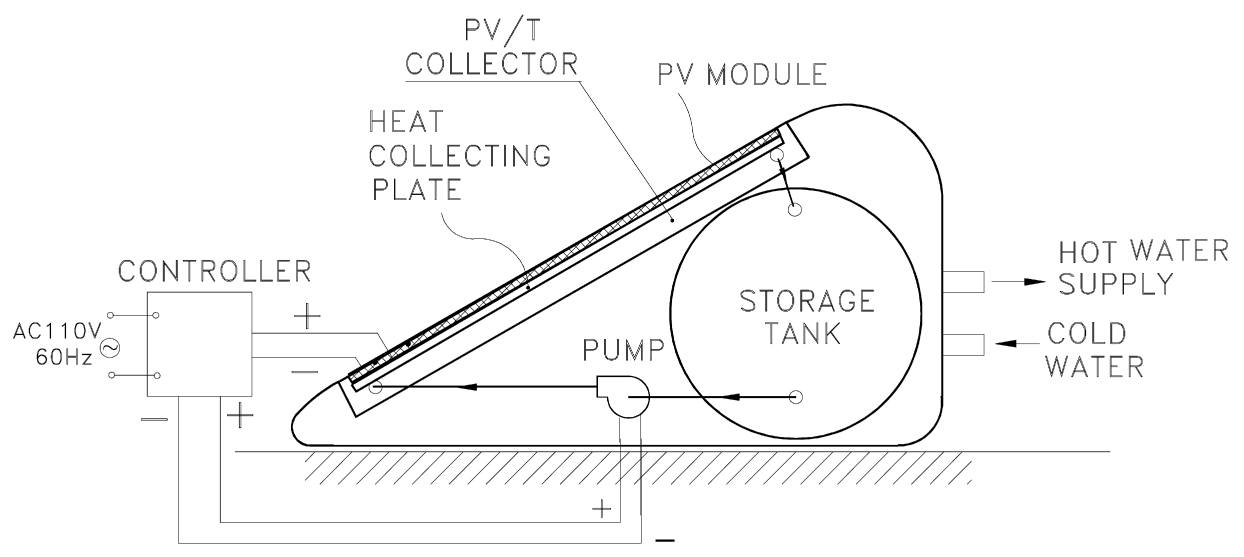

Fig. 1. Schematic diagram of integrated PV/T system (IPVTS).

IPVTS and measured the thermal performance using the daily-efficiency test procedure for a solar hot water heater (Huang and Du, 1991). The overall evaluation of an IPVTS is also carried out using the concept of primary-energy saving.

\section{PV/T SYSTEM EVALUATION}

Many researchers (Bergene and Bjerke, 1993; Bergene and Lovik, 1995; Fujisawa and Tani, 1997; Garg et al., 1990; Hayakashi et al., 1990; Lalovic, 1986/87) used the total efficiency $\eta_{\mathrm{o}}$ which is defined in Eq. (1), for evaluating the $\mathrm{PV} / \mathrm{T}$ systems:

$\eta_{\mathrm{o}}=\eta_{\mathrm{th}}+\eta_{\mathrm{e}}$

It is known that the value of electric power and thermal energy differs due to the form of energy. Electric energy is a high-grade form of energy since it is converted from thermal energy. Hence, to correctly evaluate the energy saving of a PV/T system, we define the energy-saving efficiency, in terms of the primary-energy saving, as

$E_{\mathrm{f}}=\eta_{\mathrm{e}} / \eta_{\text {power }}+\eta_{\mathrm{th}}$

where $\eta_{\mathrm{e}}$ is the electric power generation efficiency for solar PV; $\eta_{\text {power }}$ is the electric power generation efficiency for a conventional power plant; $\eta_{\mathrm{th}}$ is the heat collection efficiency of the $\mathrm{PV} / \mathrm{T}$ system. $\eta_{\text {power }}$ is taken as 0.38 in the present study. For simplicity the efficiency of conventional heating systems has been assumed to be $100 \%$. It has been found by Huang (1993) that the daily efficiency for most solar hot water heaters with a cold-water start (low initial water temperature daily) is around 0.50 . This value will provide a criterion for checking the overall performance of a PV/T system. It is expected that the primary-energy saving efficiency $E_{\mathrm{f}}$ for a $\mathrm{PV} / \mathrm{T}$ system should exceed 0.50 in order to compete with a pure solar hot water system.

\section{IPVTS HARDWARE DESIGN AND TESTS}

The PV/T collector made in the present study comprises a commercial PV module and a heatcollecting plate (Fig. 2). A Solarex MSX60 polycrystalline solar PV module $(467 \mathrm{~mm} \times 1105 \mathrm{~mm})$ (rated $60 \mathrm{Wp}, 17.1 \mathrm{~V}$ peak voltage) was adopted to be combined with a heat-collecting plate. The heat-collecting plate adheres directly to the back of the commercial PV module. Thermal grease was used between the plate and the PV module for better contact. Below the heat collecting plate, a PU thermal insulation layer is attached using a fixing frame.

Two types of tube-in-sheet heat-collecting plates with $W / D=6.2$ and 10 have been made in the present study (Huang et al., 1999). The first one $(W / D=6.2)$ is made from extruded tube-insheet aluminum, the latter $(W / D=10)$ uses copper tube which is attached to an aluminum plate using thermally conductive adhesive. However, the performance of the $\mathrm{PV} / \mathrm{T}$ collectors with these two heat-collecting plates is not satisfactory. We thus designed a heat-collecting plate using a corrugated plate made of polycarbonate material. The flow channels in the heat-collecting plate are in the corrugated structure with $W / D=1.0$ (Fig. 3 ). The heat transfer can be greatly enhanced. The flow channel dimension is $6 \mathrm{~mm}$ in width, $4 \mathrm{~mm}$ in height, $0.6 \mathrm{~mm}$ in thickness, and $6 \mathrm{~mm}$ in rib spacing.

An IPVTS was first built using the PV/T collector combined with a water storage tank, which is insulated with 50-mm-thick PU foam. To enhance the heat transfer of the heat-collecting 


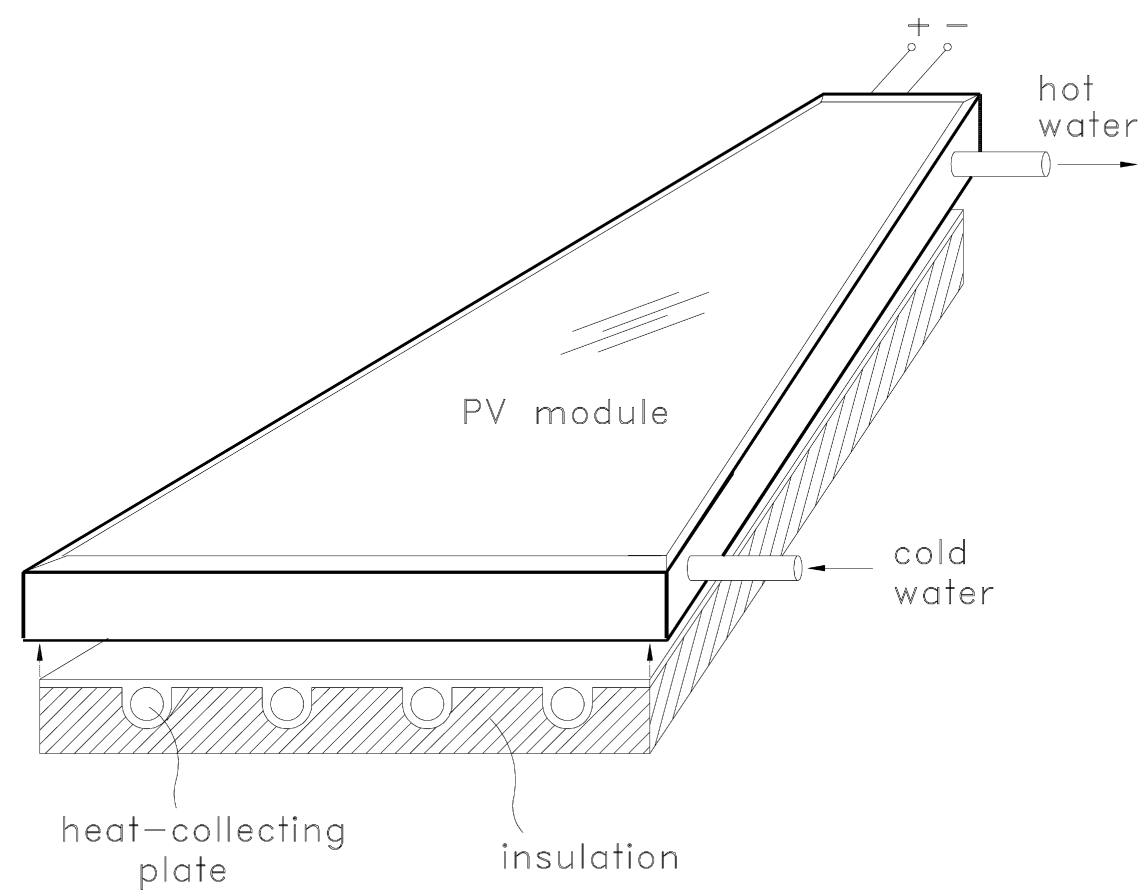

Fig. 2. Schematic diagram of PV/T collector.

plate, we installed a $3 \mathrm{~W}$ DC pump to circulate the water from the tank through the PV/T collector (Fig. 1).

For a solar water heater, there exists a critical inlet water temperature $T_{\text {in }}^{+}$that is proportional to the ambient temperature $T_{\mathrm{a}}$, the solar radiation intensity $I_{\mathrm{T}}$, and the thermal parameters of the solar collector (ratio of radiation heat absorption to convective heat loss) (Duffie and Beckmen, 1980). Once the water temperature in the storage tank $T_{\mathrm{w}}\left(=T_{\mathrm{in}}\right)$ is higher than $T_{\mathrm{in}}^{+}$, the solar collector will have a negative efficiency for solar

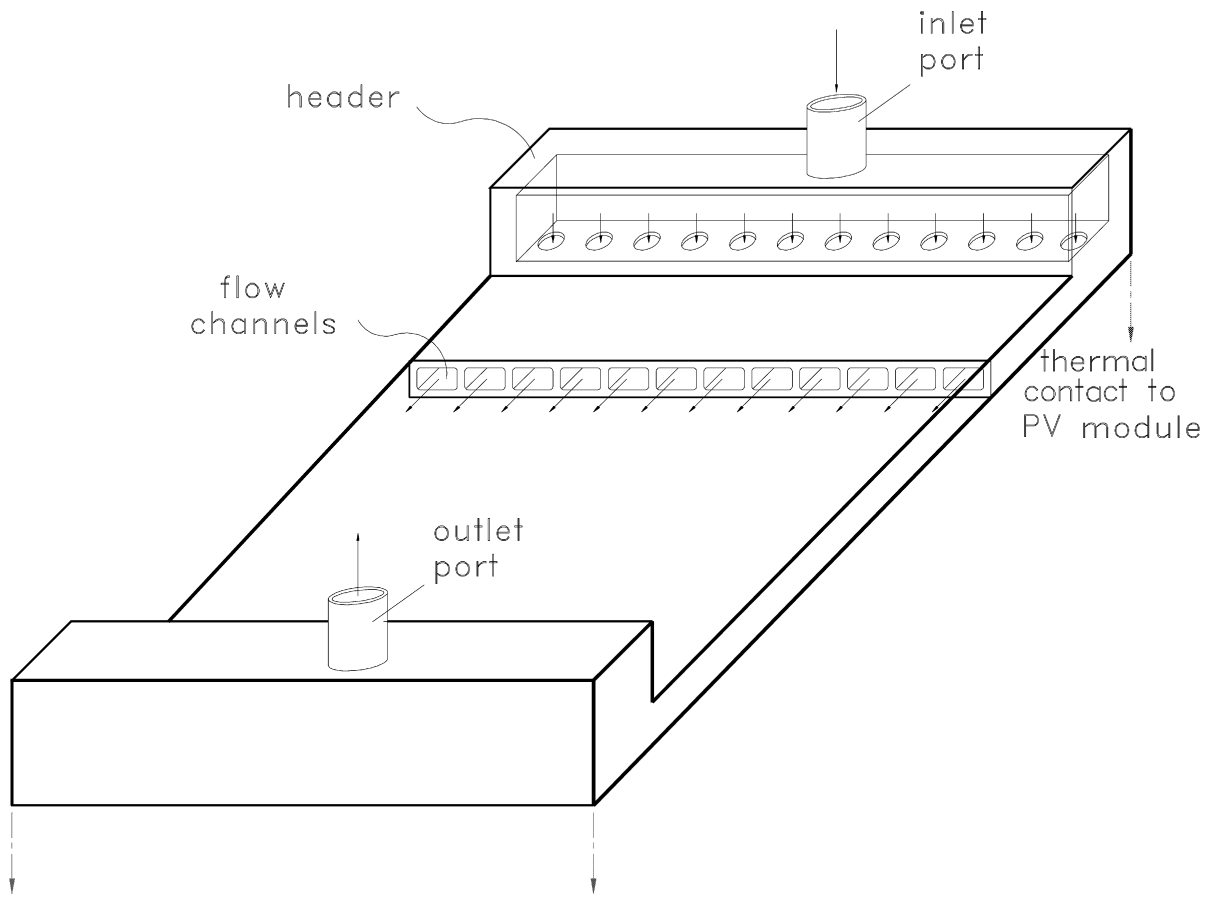

Fig. 3. Schematic diagram of heat-collecting plate. 
energy absorption. Under this condition, the pump should be shut down. In a conventional forcedcirculation solar hot water system, a DT (differential-temperature) controller controls the pump by sensing the temperature difference between the tank and the exit of the collector. The DC pump was directly controlled by a DT controller (setting $7^{\circ} \mathrm{C}$ ON and $3^{\circ} \mathrm{C}$ OFF) using a PC for the experiment.

The water volume stored in the tank in the IPVTS is 451 , which makes $V_{\mathrm{t}} / A_{\mathrm{c}}=82 \mathrm{1} / \mathrm{m}^{2}$. The IPVTS is tested using the testing standard for conventional solar hot water heaters (Huang and $\mathrm{Du}, 1991)$. The electrical power generation efficiency of the PV module is 0.09 , which is obtained from a separate measurement.

Fig. 4 shows that the temperature of the PV module is very close to that of the water temperature in the tank, within $4^{\circ} \mathrm{C}$ difference. This means that very good heat transfer is obtained between the PV module and the heat-collecting plate. The water temperature starts to saturate at 15:00 h.

The daily test results are shown in Fig. 5 and Table 1. It can be seen that the primary-energy saving efficiency $E_{\mathrm{f}}$ exceeds 0.60 for cold-start conditions (low initial temperature). As shown in Fig. 5, the characteristic efficiency of the solar $\mathrm{PV} / \mathrm{T}$ system IPVTS is $\eta_{\mathrm{s}}^{*}=0.38$. This is about $76 \%$ of the value for a conventional solar hot water heater $\left(\eta_{\mathrm{s}}^{*}=0.50\right)$. This is acceptable since

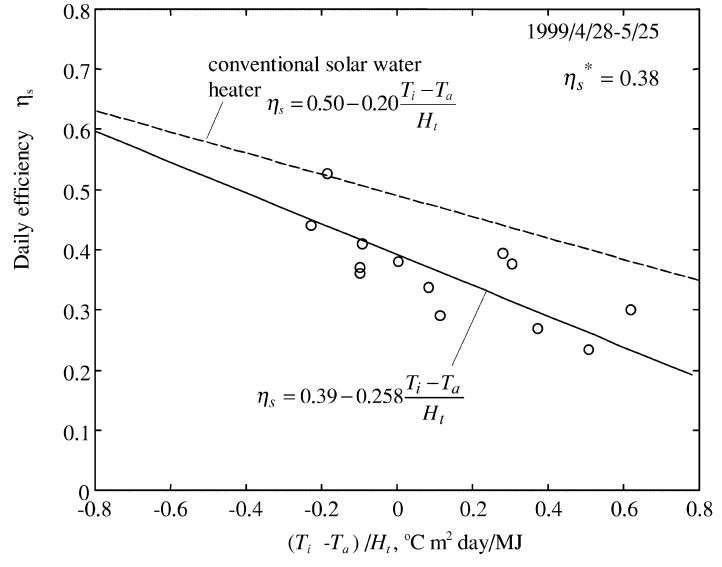

Fig. 5. Daily efficiency test results of IPVTS.

the PV/T collector of the IPVTS is an unglazed collector.

\section{DISCUSSIONS AND CONCLUSIONS}

In the present study, a commercial polycrystalline $\mathrm{PV}$ module is used for making a PV/T collector. The PV/T collector is then used to build an integral-type solar system (IPVTS). We use the testing method for conventional solar hot water heaters for the thermal performance rating of the IPVTS. It is concluded that the solar PV/T collector made from a corrugated polycarbonate panel can obtain a good thermal efficiency, with very similar temperatures (within $4^{\circ} \mathrm{C}$ difference)
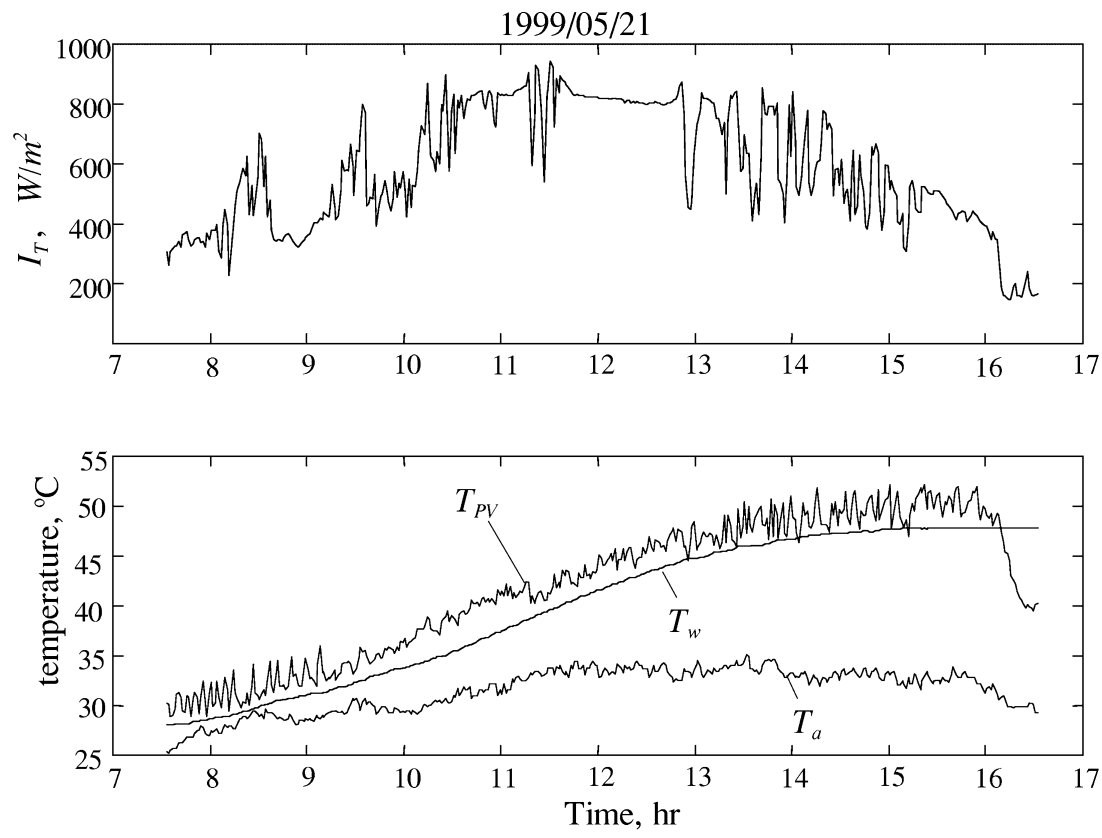

Fig. 4. A test result of IPVTS. 
Table 1. Test results of IPVTS $\left(V_{\mathrm{t}} / A_{\mathrm{c}}=82 \mathrm{1} / \mathrm{m}^{2}\right)$

\begin{tabular}{|c|c|c|c|c|c|c|c|c|}
\hline \multirow{3}{*}{$\begin{array}{l}\text { Date } \\
1999\end{array}$} & \multirow{3}{*}{$\begin{array}{l}\text { Daily total } \\
\text { solar radiation } \\
H_{\mathrm{t}}\left(\mathrm{MJ} / \mathrm{m}^{2} \text { day }\right)\end{array}$} & \multirow{2}{*}{\multicolumn{2}{|c|}{$\begin{array}{l}\text { Water temperature } \\
\text { in } \operatorname{tank}\left({ }^{\circ} \mathrm{C}\right)\end{array}$}} & \multirow[t]{3}{*}{$T_{\mathrm{a}}\left({ }^{\circ} \mathrm{C}\right)$} & \multicolumn{4}{|c|}{ Efficiency } \\
\hline & & & & & \multirow[t]{2}{*}{$\eta_{\mathrm{th}}$} & \multirow[t]{2}{*}{$\eta_{\mathrm{e}}$} & \multirow[t]{2}{*}{$\eta_{\mathrm{o}}$} & \multirow[t]{2}{*}{$E_{\mathrm{f}}$} \\
\hline & & Initial $T_{\mathrm{i}}$ & Max & & & & & \\
\hline $05 / 02$ & 6.9 & 25.4 & 33.3 & 25.4 & 0.385 & 0.09 & 0.475 & 0.622 \\
\hline $05 / 03$ & 7.3 & 28.1 & 37.3 & 28.8 & 0.411 & 0.09 & 0.501 & 0.648 \\
\hline $05 / 08$ & 15.7 & 28.2 & 45.8 & 29.8 & 0.372 & 0.09 & 0.462 & 0.609 \\
\hline $05 / 11$ & 15.9 & 25.7 & 43.1 & 27.3 & 0.363 & 0.09 & 0.453 & 0.600 \\
\hline $05 / 13$ & 12.2 & 34.5 & 44.3 & 30.0 & 0.271 & 0.09 & 0.361 & 0.508 \\
\hline $05 / 17$ & 10.0 & 32.9 & 42.8 & 32.1 & 0.337 & 0.09 & 0.427 & 0.574 \\
\hline $05 / 18$ & 15.3 & 35.7 & 49.0 & 34.0 & 0.291 & 0.09 & 0.381 & 0.528 \\
\hline $05 / 21$ & 15.2 & 28.0 & 47.7 & 31.5 & 0.445 & 0.09 & 0.535 & 0.613 \\
\hline $05 / 23$ & 9.6 & 35.0 & 46.2 & 32.1 & 0.376 & 0.09 & 0.466 & 0.613 \\
\hline $05 / 24$ & 9.7 & 40.0 & 43.9 & 31.7 & 0.122 & 0.09 & 0.212 & 0.359 \\
\hline $05 / 25$ & 6.6 & 35.3 & 40.6 & 29.6 & 0.232 & 0.09 & 0.322 & 0.469 \\
\hline
\end{tabular}

between the water in the tank and the PV module. Further improvement of the performance of the IPVTS is however possible with good insulation design of the PV/T collector, a better control scheme for the DT controller, and the packaging of the PV module and the heat-collecting plate.

The present study introduces the concept of primary-energy saving efficiency for the evaluation of a PV/T system from the point of view of primary energy gain. The present test results show that the primary-energy saving efficiency of an IPVTS exceeds 0.60 , that is, larger than for a pure solar hot water heater or a pure PV system. The characteristic daily efficiency $\eta_{\mathrm{s}}^{*}$ reaches 0.38 , which is about $76 \%$ of the efficiency of a conventional solar hot water heater using a glazed collector $\left(\eta_{\mathrm{s}}^{*}=0.50\right)$.

We chose a commercial PV module for making a PV/T collector since the major purpose of the present study is to understand the performance of an IPVTS as compared to a conventional solar water heater and to demonstrate the idea of an IPVTS design. The present PV/T collector is an unglazed collector and thus has an additional thermal resistance of the silicone-encapsulated EVA material at the back surface and the thermal grease for good thermal contact between the solar PV module and the heat-collecting plate. A lower thermal performance is expected. However, the present test results show that the characteristic daily efficiency $\eta_{\mathrm{s}}^{*}$ of the IPVTS is 0.38 , which is about $76 \%$ of the efficiency of a conventional solar hot water heater using a glazed collector $\left(\eta_{\mathrm{s}}^{*}=0.50\right)$. This indicates that the performance of a PV/T collector can be improved if the heatcollecting plate is in direct thermal contact with the PV cells and the heat-collecting plate is used as the base plate of the PV cells. In addition, the glass cover and the PV cells can be separated to make an air-insulating layer between the glass and solar cells so that the PV/T collector will become a glazed collector. This design can be easily implemented in the manufacturing process. That is, the PV/T collector actually combines the manufacturing of the PV module and the thermal collector in a single manufacturing process. The manufacturing cost can be reduced. If the $\mathrm{PV} / \mathrm{T}$ collector is integrated with a storage tank to make an IPVTS, the system cost can also be reduced further. The present study shows that the idea of an IPVTS is economically feasible too.

Finally, we would like to point out that the overall performance of a $\mathrm{PV} / \mathrm{T}$ system, including thermal and electric conversion, is affected by many factors. The thermal efficiency decreases with increasing hot water temperature. Increasing hot water temperature in order to meet some application requirements would in turn cause the power generation efficiency of solar PV to decrease. Besides, the unit costs of thermal energy collection and electric power generation are different. A new cost function that takes into account the energy gain per unit investment is necessary for system optimization including economic feasibility. A system simulation using meteorological data for a particular design of PV/T system can help to obtain the optimum system design based on the total primary-energy gain per unit investment. This remains for further studies in the future.

\section{NOMENCLATURE}

\begin{tabular}{|c|c|}
\hline$A_{\mathrm{c}}$ & $\begin{array}{l}\text { collector area (taken as PV module area), } \mathrm{m}^{2} \\
\text { tube diameter } \mathrm{m}\end{array}$ \\
\hline$D$ & tube diameter, $\mathrm{m}$ \\
\hline$H_{\mathrm{t}}$ & $\begin{array}{l}\text { accumulated solar incident radiation upon col- } \\
\text { lector surface, } \mathrm{MJ} \mathrm{m}^{-2}\end{array}$ \\
\hline$T_{\mathrm{a}}$ & ambient temperature, ${ }^{\circ} \mathrm{C}$ \\
\hline$T_{\mathrm{i}}$ & initial water temperature in tank, ${ }^{\circ} \mathrm{C}$ \\
\hline$T_{\text {in }}$ & inlet water temperature of $\mathrm{PV} / \mathrm{T}$ collector, ${ }^{\circ} \mathrm{C}$ \\
\hline$T_{\mathrm{f}}$ & final water temperature in tank, ${ }^{\circ} \mathrm{C}$ \\
\hline$T_{\text {out }}$ & outlet water temperature of $\mathrm{PV} / \mathrm{T}$ collector, ${ }^{\circ} \mathrm{C}$ \\
\hline$T_{\mathrm{pv}}$ & temperature of $\mathrm{PV}$ panel, ${ }^{\circ} \mathrm{C}$ \\
\hline
\end{tabular}


$T_{\mathrm{w}} \quad$ water temperature in the tank, ${ }^{\circ} \mathrm{C}$

$V_{\mathrm{t}} \quad$ water storage volume in tank, $\mathrm{m}^{3}$

$V_{\mathrm{t}} / A_{\mathrm{c}} \quad$ ratio of water storage to collector area, $\mathrm{m}^{3} \mathrm{~m}^{-2}$ or $1 \mathrm{~m}^{-2}$

$W \quad$ tube spacing, $\mathrm{m}$

$\eta_{\mathrm{s}} \quad$ daily efficiency of solar hot water heater defined by Huang (1993)

$\eta_{\mathrm{s}}^{*} \quad$ characteristic daily efficiency of solar hot water heater defined by Huang (1993)

Acknowledgements-The present study was supported by the National Science Council, Taiwan, ROC, through grant no. NSC87-TPC-E-002-016.

\section{REFERENCES}

Bergene T. and Bjerke B. (1993) Thermodynamic considerations concerning the efficiency and possible utilization of combined quantum/thermal solar energy converters. Proceedings ISES Solar World Congress, Budapest Vol. 4, 25-30.

Bergene T. and Lovik O. (1995) Model calculations on a flat-plate solar heat collector with integrated solar cells. Solar Energy 55(6), 453-462.

Duffie J. A. and Beckman W. A. (1980) Solar Engineering of Thermal Processes. John Wiley and Sons, New York.

Fujisawa T. and Tani T. (1997) Binary utilization of solar energy with photovoltaic-thermal hybrid collector. In ISES 1997 Solar World Congress, Aug. 24-28, Taejon, Korea.

Garg H. P., Bharagaba A. K. and Agarwal R. K. (1990) Experimental and theoretical studies on a photovoltaic/ thermal hybrid solar collector water heater. Proceedings 1989 Congress ISES Vol. 1, 701-705.

Hayakashi B., Mizusaki K., Satoh T. and Hatanaka T. (1990) Research and development of photovoltaic/thermal hybrid solar power generation system. Proceedings 1989 Congress ISES Vol. 1, 302-306.

Huang B. J. and Du S. C. (1991) A performance test method of solar thermosyphon systems. ASME J. Solar Energy Eng. 113, 172-179.

Huang B. J. (1993) Performance rating method of thermosyphon solar water heaters. Solar Energy 50(5), 435440.

Huang B. J., Lin T. H. and Hong W. T. (1999) Solar photovoltaic/thermal co-generation collector. In ISES Solar World Congress, Jerusalem, Israel, July 4-9.

Lalovic B. (1986/87) A hybrid amorphous silicon photovoltaic and thermal solar collector. Solar Cells 19, 131-138. 